\title{
Effect of ampicillin and chloroquine on humoral immune response elicited by bovine albumin encapsulated in liposomes
}

\author{
JITENDER MADAN ${ }^{1}$ \\ DINESH KAUSHIK ${ }^{1}$ \\ SATISH SARDANA ${ }^{1, *}$ \\ DINA NATH MISHRA ${ }^{2}$ \\ SHALINDER KUMAR SINGH ${ }^{2}$ \\ BINOD KUMAR SINGH ${ }^{3}$ \\ ${ }^{1}$ Department of Pharmaceutics \\ Hindu College of Pharmacy \\ Sonepat (Haryana), India \\ ${ }^{2}$ Department of Pharmaceutical Sciences \\ Guru Jambheshwar University of Science \\ and Technology, Hisar (Haryana) India \\ ${ }^{3}$ Department of Pharmacy \\ Kumaon University, Nainital, India
}

Accepted October 24, 2008

\begin{abstract}
Immune suppression resulting from chemoprophylaxis and potential drug interaction were investigated in experimental animals pre-medicated with ampicillin and chloroquine followed by immunization with bovine serum albumin bearing liposomes prepared by the reverse phase evaporation method. The prepared liposomes were evaluated for particle size, entrapment efficiency and in vitro release. Humoral immune response was measured in terms of systemic IgG antibody titre by the ELISA method. The present study showed that 7:3 molar ratio of soya phosphatidylcholine and cholesterol produced liposomes of mean diameter of $235.4 \pm 10.3 \mathrm{~nm}$ and entrapment efficiency of $41.3 \pm 3.2 \%$. Ampicillin significantly $(p<0.05)$ decreased the antibody titre whereas chloroquine did not reduce the antibody titre significantly. The study will help in programming a new drug management and in characterization of vaccine-drug interaction.
\end{abstract}

Keywords: immunomodulation, liposomes, bovine albumin, ampicillin, chloroquine

Several studies have been conducted to establish the phenomenon of vaccine-drug interaction against various categories of chemotherapeutic agents, such as fluoroquinolones and chloramphenicol (1). They can either increase or decrease the phagocytic function or modulate the immune response triggered by an antigen (2). Investigations have revealed that chloroquine prophylaxis for malaria is associated with an impaired antibody response to rabies vaccine administered intradermally (3). It was proposed that chloroquine might interfere with the antigen processing mechanism and T-cell recognition $(4,5)$. In addition, chloroquine raises $\mathrm{pH}$ within lysosomes and thus interferes with the fusion of viral and lysosomal membranes, which is necessary to release viral nucleocapsid. It has been also shown that chloroquine interferes with secretion of interleukin-1 (IL-1) by monocytes, inhibiting the generation of immunoglobulin secretary lymphocytes (4). However, chloroquine did not affect the antibody response of yellow fever vac-

\footnotetext{
* Correspondence, e-mail: sardanasatish@gmail.com
} 
cine (6). Hence, the antigens showed different immune response profiles in dependance on antigen types; therefore, the interaction of drugs with the immune response after immunization would be different. For many of these agents, the underlying mechanisms of immunomodulation are not well defined and some events are strongly dependent on the method applied. However, studies on immunomodulation by antibiotics are still in infancy and the methods applicable for its assessment are continually improving. On the other hand, vesicular systems are better than traditional vaccine adjuvants. Immunological adjuvants such as Freund's complete and incomplete adjuvant, bacterial endotoxins, polyanions, mineral adsorbents (inducing local or systemic toxicity) form unacceptable granulomas or may lack efficiency (7). The use of vesicular systems like liposomes as carriers of peptides, proteins and DNA vaccines require simple, easy to scale up technology, capable of high yield vaccine entrapment (8). It is well known that controlled release of antigens is the only way of achieving a long-lasting boosting effect. Studies have revealed that liposomes entrapping bovine serum albumin enhanced systemic and mucosal immune response following oral administration of liposomes (9). It was found that rapid targeting of massive doses of antigenic material to antigen presenting cells (APCs), especially macrophages, have, however, often been the principal source of liposomal adjuvanticity (10). Although many research methodologies have been applied so far to elucidate the mechanism of immunomodulation by chemotherapeutic agents, no concise conclusion has been drawn due to antigenic variation. Hence, in the present investigation, a protein antigen, BSA (bovine serum albumin), was encapsulated in a vesicular system (liposomes) and the effect of ampicillin and chloroquine (selected as the model drugs) on the humoral immune response was evaluated. In the present work, an effort has been made to provide an inexpensive and sensitive method for the preliminary screening of chemotherapeutic agents for their immunomodulating activity.

\section{EXPERIMENTAL}

\section{Materials}

Bovine serum albumin (BSA) and cholesterol AR $(\mathrm{CH})$ were purchased from the Central Drug House, New Delhi, India. Soya phosphatidylcholine (SPC) and Sephadex G-150 were purchased from Sigma (USA). Ampicillin ( $1 \mathrm{~g}$ vial) and chloroquine (Resochin injection, $40 \mathrm{~g} \mathrm{~L}^{-1}$, 30-mL vial) were purchased from Zydus Cadila and Bayer Pharmaceuticals, India, respectively. ELISA kit (Specific anti-rat IgG) was purchased from Gennei, India. All other chemicals used were of analytical grade.

\section{Methods}

Preparation of liposomes. - Liposomes were prepared by the reverse phase evaporation technique (11). Briefly, SPC and $\mathrm{CH}\left(\mathrm{mol} \mathrm{L}^{-1}\right)$ were dissolved in 5-mL of diethyl ether (organic phase) in a glass boiling tube, to which 2-mL of aqueous phase, phosphate-buffer saline (PBS, $\left.10 \mathrm{mmol} \mathrm{L}^{-1}, \mathrm{pH} 7.4\right)$ containing BSA $\left(1 \mathrm{~g} \mathrm{~L}^{-1}\right)$ was added. The mixture was sonicated (Soniweld, India) for $5 \mathrm{~min}$ at $4{ }^{\circ} \mathrm{C}$ and was attached to a rotary evaporator to dry the contents at $37^{\circ} \mathrm{C}$ under vacuum $(250 \mathrm{~mm} \mathrm{Hg})$ until a gel was formed. Vac- 
uum was released and the tube was removed from the evaporator and subjected to vigorous mechanical agitation on a vortex mixer for $5 \mathrm{~min}$. When the gel collapsed to fluid, it was again fitted to the rotary flash evaporator for removal of the organic solvent. After 10 min drying and 5 min vortexing, this was repeated twice again. The final liposomal suspension was subjected to complete removal of the last traces of organic solvent in the rotary flash evaporator under vacuum $(600 \mathrm{~mm} \mathrm{Hg})$ for $15 \mathrm{~min}$. To this emulsion, $3 \mathrm{~mL}$ of PBS (pH 7.4) was added to hydrate the mixture, resulting in formation of large unilamellar vesicles. The resulting large unilamellar vesicles were passed 5 times through 0.45-and 10 times through $0.2-\mu \mathrm{m}$ polycarbonate membrane (MDI, India).

Determination of vesicle size. - The mean diameter of liposomes was measured by photon correlation spectroscopy with an autosize II C apparatus (Malvern Instruments, UK) in PBS (pH 7.4).

Entrapment efficiency. - About $0.2 \mathrm{~mL}$ of liposomes was eluted with PBS (pH 7.4) through Sephadex G-150 minicolumn to separate unentrapped antigen (12). The method was repeated thrice with a fresh syringe packed with gel each time. The fraction was finally collected free from unentrapped antigen. To the vesicular fraction, a minimum amount of Triton X-100 $(0.5 \%, m / V)$ was added to disrupt the vesicles. The liberated antigen was estimated by using the BCA (bicinchoninic acid) protein assay at $562 \mathrm{~nm}$ and percent antigen entrapment was calculated (13). Liposome recovery was $95.3 \pm 2.2 \%$.

In vitro release of the antigen. - In vitro drug release profile of the antigen was studied using the dialysis technique (14). First, the liposomal formulation was centrifuged at $12857 \times g$ for 2 minutes through Sephadex G-150 column to remove unentrapped drug. Subsequently, $2.0 \mathrm{~mL}$ of liposomal suspension (without unentrapped antigen) was taken into a dialysis tube (Sigma) and placed in a beaker containing $10 \mathrm{~mL}$ of PBS (pH 7.4). The beaker was placed over a magnetic stirrer, and the temperature of the assembly was maintained at $37 \pm 1{ }^{\circ} \mathrm{C}$ throughout the study. Samples were withdrawn at predetermined time intervals $(2,4,6,8,10,12,24$ and $48 \mathrm{~h})$ and replaced with PBS (pH 7.4) to mimic infinite sink conditions. The process was repeated thrice and the samples were analyzed for BSA at $562 \mathrm{~nm}$ (13).

Stability study on storage. - The ability of vesicles to retain the antigen was assessed by keeping the liposomal suspension in sealed vials (10 mL capacity) after flushing with nitrogen at $4 \pm 0.5,25 \pm 0.5$ and $37 \pm 0.5{ }^{\circ} \mathrm{C}$ for one month under controlled conditions and then evaluated for their size and leaked percent of encapsulated BSA using BCA at $562 \mathrm{~nm}$. The initial antigen content was considered as $100 \%$.

Medication and immunization. - In vivo studies were carried out as per guidelines compiled by CPCSEA (Committee for the Purpose of Control and Supervision of Experiments on Animals), Ministry of Culture, Government of India. The Institutional Animal Ethics Committee approved the study. Male albino rats (Wistar strain, $80 \pm 20 \mathrm{~g}$ ) were maintained at standard laboratory chow and water ad libitum in a temperature and light controlled environment at the Hindu College of Pharmacy (Sonepat, Haryana, India). Animals were divided into seven groups of six animals each. Ampicillin and chloroquine were injected i.m. as per the therapeutic dose-dosage regimen based on the body mass of rats (Table III). Simultaneously, ampicillin and chloroquine-treated rats were immunized subcutaneously with a single dose of $100-\mu \mathrm{g}$ equivalent of BSA-loaded liposomes as the $100-\mu \mathrm{g}$ of BSA encapsulated in vesicular system induced significantly higher antibody titre than the equivalent amount of BSA emulsified in Freund's complete adjuvant (14). 
Immunization was done after pre-medication of albino rats with ampicillin and chloroquine (Table III) applying three variables - following medication (FM), after seven days of medication (ASDM) and during medication (DM). The immune response of BSA-loaded liposomes (without medication) was regarded as the control (CONTR) group.

Determination of IgG titre by ELISA. - Specific anti-BSA antibody level in the serum was determined by ELISA (15). Each well of the flat-bottomed polystyrene plates was coated with $100-\mu \mathrm{L}$ of BSA ( $1 \mathrm{mg} \mathrm{L}^{-1}$ in $0.02 \mathrm{~mol} \mathrm{~L}^{-1}$ Tris $\left./ \mathrm{HCl}, \mathrm{pH} 9.0\right)$ and incubated overnight at $4{ }^{\circ} \mathrm{C}$. Thereafter, the wells were washed ten times with PBS-Tween buffer (0.02 mol L-1 Tris, $0.05 \% \mathrm{~V} / V$ Tween 20, $\mathrm{pH} 7.4$ ) and to each well, $100-\mu \mathrm{L}$ of the diluted serum sample was added and incubated for $2 \mathrm{~h}$ at room temperature. The plates were washed three times with PBS-Tween buffer and $100-\mu \mathrm{L}$ of diluted horseradish-peroxidase-conjugated anti-globulin-specific anti-rat IgG was added to each well and incubated for $2 \mathrm{~h}$. The plates were again washed three times with PBS-Tween buffer and $100-\mu \mathrm{L}$ of substrate solution 3,3',5,5'-tetramethyl benzidine containing hydrogen peroxide was added to each well. The plates were incubated in dark at room temperature for $15 \mathrm{~min}$. The reaction was stopped by adding $50-\mu \mathrm{L}$ of $2 \mathrm{~mol} \mathrm{~L}^{-1} \mathrm{H}_{2} \mathrm{SO}_{4}$ to each well and the absorbance was measured at $450 \mathrm{~nm}$ using a microplate ELISA reader (Lab System Multiscan, Finland). The immune response was shown in terms of reciprocal end point dilution.

Statistical analysis. - The results were expressed as mean \pm standard deviation. Statistical analysis was carried out using the one-way ANOVA and two-way ANOVA tests. All statistical calculations were performed with the GRAPH PAD Prism 4.01 software.

\section{RESULTS AND DISCUSSION}

\section{Preparation and characterization of vesicular system}

The present study was performed to evaluate the effect of ampicillin and chloroquine prophylaxis on the humoral immune response elicited by bovine serum albumin encapsulated in liposomes, acting as an efficient carrier for delivery of proteins and peptides (8). Liposomes were prepared using the reverse phase evaporation technique, associated with relatively higher encapsulation efficiency of macromolecules such as antigens and peptides (11). The nature of the buffer used to dissolve the antigen with respect to composition; $\mathrm{pH}$ and molarity did not interfere with liposome formation or the yield of entrapment (8). The prepared vesicular system was characterized for particle size, entrapment efficiency, in vitro release and storage stability profile. The particle size of liposomal formulation was measured by photon correlation microscopy. On the basis of entrapment efficiency and particle size, different molar ratios of SPC and $\mathrm{CH}$ were taken for the preparation of liposomes (Table I). It was observed that formulation LPS-3 (7:3 $\mathrm{mol} \mathrm{L}^{-1}$, SPC and $\mathrm{CH}$ ) produced liposomes of $235.4 \pm 10.3 \mathrm{~nm}$ mean diameter with maximum entrapment efficiency of $41.3 \pm 3.2 \%$ of antigen. Hence, the data of liposomal formulations justified the results reported earlier in which the optimized liposomal formulation was used for vaccination (14). Besides, 7:3 $\mathrm{mol} \mathrm{L}^{-1}$ of phospholipid and cholesterol produced size-controlled vesicles using the hydration method followed by sonication (16). Hence, the optimized formulation LPS-3 was then considered for in vitro release experimentation and storage stability study. Data of the in vitro release study indicated that 
J. Madan et al.: Effect of ampicillin and chloroquine on humoral immune response elicited by bovine albumin encapsulated in liposomes, Acta Pharm. 58 (2008) 479-487.

Table I. Composition and characterization of BSA-loaded liposomal formulations

\begin{tabular}{cccc}
\hline $\begin{array}{c}\text { Formulation } \\
\text { code }\end{array}$ & $\begin{array}{c}\text { Composition } \\
(\mathrm{SPC}: \mathrm{CH})\left(\mathrm{mol} \mathrm{L}^{-1}\right)\end{array}$ & $\begin{array}{c}\text { Entrapment efficiency } \\
(\%)^{\mathrm{a}}\end{array}$ & $\begin{array}{c}\text { Mean vesicle size } \\
(\mathrm{nm})^{\mathrm{a}}\end{array}$ \\
\hline LPS-1 & $9: 1$ & $29.5 \pm 2.3$ & $221.3 \pm 11.6$ \\
LPS-2 & $8: 2$ & $35.4 \pm 4.1$ & $230.5 \pm 9.8$ \\
LPS-3 & $7: 3$ & $41.3 \pm 3.2$ & $235.4 \pm 10.3$ \\
LPS-4 & $6: 4$ & $34.2 \pm 3.6$ & $236.6 \pm 15.4$ \\
LPS-5 & $5: 5$ & $32.3 \pm 3.2$ & $240.2 \pm 9.5$ \\
\hline
\end{tabular}

a Mean $\pm \mathrm{SD}, n=3$.

$4.3 \%$ of BSA was released from the vesicular system (liposomes) after $8 \mathrm{~h}$ in phosphate buffer saline ( $\mathrm{pH} 7.4$ ). However, only $11.1 \%$ of BSA was released over $48 \mathrm{~h}$, exhibiting fast initial release, followed by slow release (Fig. 1). Slow release of the entrapped antigen could be due to the large molecular size of the antigen $(69,000 \mathrm{D})$ with poor diffusitivity through the vesicular membrane. However, the small amount of antigen released quickly at the initial stage might be attributed to the surface adsorbed antigen. Moreover, cholesterol affects profoundly the liposomal membrane properties. Incorporation of cholesterol in the gel-state bi-layer can induce continuous and permanent transition to an ordered liquid crystalline state, which contributes to slow release characteristics. Further, stability (in the process as well as in storage) is very important especially in the case of immunological products since denaturation or deactivated antigen will lead to generation of an insufficient immune response, making the subject prone to the disease against which the immunization is being carried out. In storage at $4 \pm 0.5,25 \pm 0.5$ and $37 \pm 0.5^{\circ} \mathrm{C}$ for 30 days, it was observed that around $6.8 \%$ of antigen was leaked from optimized formulation LPS-3 stored at $4 \pm 0.5{ }^{\circ} \mathrm{C}$ compared to 11.1 and $19.9 \%$ of that stored at $25 \pm 0.5$ and $37 \pm 0.5{ }^{\circ} \mathrm{C}$, respectively (Table II). A non-significant difference in vesicle size was observed in formulation LPS-3 stored at $4 \pm 0.5^{\circ} \mathrm{C}$. Hence, the formulation stored at $4 \pm 0.5^{\circ} \mathrm{C}$ demonstrated a very low antigen leakage compared to the formulation stored at $25 \pm 0.5^{\circ} \mathrm{C}$ and $37 \pm 0.5^{\circ} \mathrm{C}$, respectively, suggesting that refrigerated conditions are well suited to the developed formulation. It was demonstrated previously in a long-term storage stability study that liposomes were stable for over 1 year (17).

Fig. 1. In vitro release profile of BSA from the liposomal (LPS-3) formulation (mean $\pm \mathrm{SD}, n=3$ ).

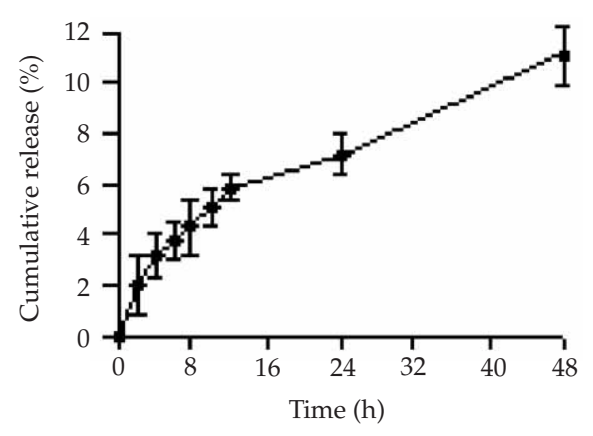


J. Madan et al.: Effect of ampicillin and chloroquine on humoral immune response elicited by bovine albumin encapsulated in liposomes, Acta Pharm. 58 (2008) 479-487.

Table II. Study of storage stability of the BSA-loaded liposomal (LPS-3) formulation

\begin{tabular}{crrr}
\hline \multirow{2}{*}{ Parameter } & \multicolumn{3}{c}{ Storage temperature $\left({ }^{\circ} \mathrm{C}\right)$} \\
\cline { 2 - 4 } & $4 \pm 0.5$ & $25 \pm 0.5$ & $37 \pm 0.5$ \\
\hline Residual BSA $(\%)^{\mathrm{a}}$ & $93.2 \pm 4.1$ & $89.9 \pm 4.6$ & $80.1 \pm 3.1$ \\
Vesicle size $(\mathrm{nm})^{\mathrm{a}}$ & $245.4 \pm 4.6$ & $305.8 \pm 8.5$ & $410.5 \pm 7.8$ \\
\hline
\end{tabular}

a Mean $\pm \mathrm{SD}, n=3$.

\section{Systemic IgG response}

We have investigated the effect of ampicillin and chloroquine on the humoral immune response in albino rats triggered by bovine serum albumin entrapped liposomes. The optimized formulation (LPS-3) was used for vaccination of animals. The specific anti-rat IgG antibody titre was measured after 21 days in all medicated and control groups (after immunization) by the ELISA technique and the results were expressed as reciprocal end point dilution.

\section{Effect of ampicillin on IgG antibody titre}

In vivo study indicated that ampicillin in therapeutic dose-dosage regimen significantly $(p<0.05)$ reduced the antibody titre compared to the control group (Fig. 2). As we immunized the rats at the time of ampicillin prophylaxis, it was observed that ampicillin markedly reduced the antibody titre in two groups of animals, in the following medica-

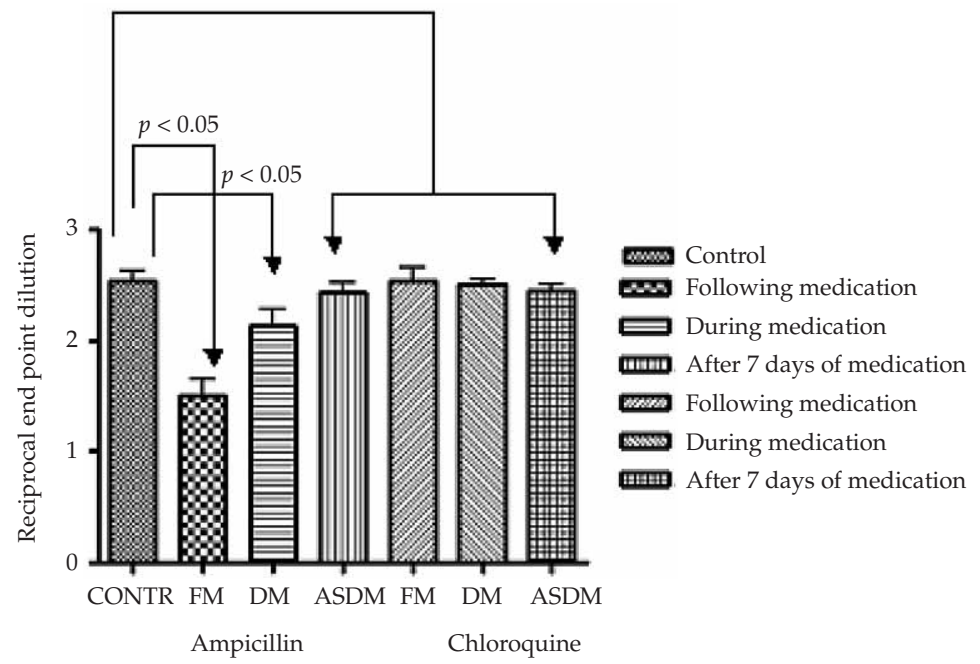

Fig. 2. Effect of ampicillin and chloroquine on the specific antirat IgG antibody titre (mean $\pm S D, n=6$ ). 
J. Madan et al.: Effect of ampicillin and chloroquine on humoral immune response elicited by bovine albumin encapsulated in liposomes, Acta Pharm. 58 (2008) 479-487.

Table III. Therapeutic dose-dosage regimen of ampicillin and chloroquine administered to rats

\begin{tabular}{|c|c|c|c|}
\hline Drug & Dose & $\begin{array}{l}\text { Duration of } \\
\text { the course }\end{array}$ & $\begin{array}{l}\text { Groups prepared for administration of the } \\
\text { drug and BSA bearing liposomes }\end{array}$ \\
\hline \multirow[t]{3}{*}{ Ampicillin } & $8.3 \mathrm{mg} \mathrm{kg}^{-1}$ & 5 days & $\begin{array}{l}\text { Following medication (rats were medi- } \\
\text { cated for } 5 \text { days and then immunized) }\end{array}$ \\
\hline & \multirow[t]{2}{*}{ (i.m.) } & & $\begin{array}{l}\text { During medication (rats were medicated } \\
\text { for } 2.5 \text { days, then immunized and medi- } \\
\text { cated again for the following } 2.5 \text { days) }\end{array}$ \\
\hline & & & $\begin{array}{l}\text { After } 7 \text { days of medication (rats were } \\
\text { medicated for } 5 \text { days, then left to rest for } \\
7 \text { days and then immunized) }\end{array}$ \\
\hline \multirow[t]{4}{*}{ Chloroquine } & \multirow{4}{*}{$\begin{array}{l}10 \mathrm{mg} \mathrm{kg}^{-1} \\
\text { for first } 8 \mathrm{~h} \text {, } \\
\text { followed by } \\
15 \mathrm{mg} \mathrm{kg}^{-1} \text { at } \\
16 \mathrm{~h} \text { and } 24 \mathrm{~h} \\
\text { (i.m.) }\end{array}$} & \multirow[t]{4}{*}{3 days } & $\begin{array}{l}\text { Following medication (rats were medi- } \\
\text { cated for } 3 \text { days and then immunized) }\end{array}$ \\
\hline & & & \multirow{3}{*}{$\begin{array}{l}\text { During medication (rats were medicated } \\
\text { for } 1.5 \text { days, then immunized and medi- } \\
\text { cated again for } 1.5 \text { days) } \\
\text { After } 7 \text { days of medication (rats were } \\
\text { medicated for } 3 \text { days, then left to rest for } \\
7 \text { days and then immunized) }\end{array}$} \\
\hline & & & \\
\hline & & & \\
\hline BSA (in liposomes) & $100-\mu g$ (s.c.) & Single dose & Control group \\
\hline
\end{tabular}

tion and during medication groups of rats, and not in the third group, after 7 days of medication, indicating the immunosuppressive effect of ampicillin. However, the absence of immunosuppression in the after-7-days-of-medication group clearly indicated that the drug was completely excreted and did not interact with immune cells to modulate the immune response. The results are concomitant with the similar structurally related drug, amoxycillin, which impaired antibody titre in rat pups immunized with oval albumin (18). In addition, researchers also categorize ampicillin as an immunodepressing antibiotic (19).

\section{Effect of chloroquine on IgG antibody titre}

Experimental data of in vivo study indicated that chloroquine did not reduce the antibody titre significantly in the three groups of rats, following medication, during medication and after 7 days of medication, compared to the control group (Fig. 2). Hence, the data suggest that chloroquine did not interfere with the immune mechanism, as did ampicillin. In contrast, chloroquine $\left(10^{-4} \mathrm{~mol} \mathrm{~L}^{-1}\right.$, plateau plasma chloroquine level) suppressed the immune response either by interfering with virus replication or macrophage function required for antibody synthesis $(5,6)$. However, the chloroquine base $(300 \mathrm{mg}$ base weekly regimen; $10^{-7} \mathrm{~mol} \mathrm{~L}^{-1}$ plateau plasma chloroquine level) was found inadequate to suppress immune response triggered by Yellow fever vaccine (20). Bovine serum albumin is a model antigenic protein and the mechanism earlier proposed for chloroquine immunomodulation does not affect the anti-BSA antibody titre. Hence, it is necessary to check the individual antigen with chloroquine to explore the phenomena of vaccine-drug interaction. 


\section{CONCLUSIONS}

In conclusion, the antigen encapsulated in liposomes induced the humoral immune response. The results indicate that ampicillin produced a significant reduction in the antibody titre $(p<0.05)$ as compared to the control group when administered in the therapeutic dose-dosage regimen, whereas chloroquine did not decrease the antibody titre significantly.

\section{REFERENCES}

1. J. Madan, D. Kaushik, S. Sardana, and D. N. Mishra, Effect of ciprofloxacin and chloramphenicol on humoral immune response elicited by bovine albumin encapsulated in niosomes, Acta Pharm. Sin. 42 (2007) 905-910.

2. M. L. Villa, G. Rappocciolo and P. Piazza, The interference of antibiotics with antigen specific antibody response in man, Int. J. Immunopharmacol. 8 (1986) 805-809; DOI: 10.1016/0192-0561 (86)90018-4.

3. M. Pappaioanou, D. B. Fishbein, D. W. Dreesen, I. K. Schwartz, G. H. Campbell, J. W. Sumner, L. C. Patchen and W. J. Brown, Antibody response to pre-exposure human diploid-cell rabies vaccine given concurrently with chloroquine, N. Engl. J. Med. 314 (1986) 280-284.

4. G. Salmeron and P. E. Lipsky, Immunosuppressive potential of antimalarials, Am. J. Med. 75 (1983) 19-24; DOI: 10.1016/0002-9343(83)91266-4.

5. D. Hurvitz and K. Hirschhorn, Suppression of in vitro lymphocyte responses by chloroquine, N. Engl. J. Med. 273 (1965) 23-26.

6. M. Barry, J. E. Patterson and S. Tirrell, The effect of chloroquine prophylaxis on yellow fever vaccine antibody response: comparison of plaque reduction neutralization test and enzyme linked immunosorbent assay, Int. J. Trop. Med. Hyg. 44 (1991) 79-82.

7. A. C. Allison and G. Gregoriadis, Vaccine: recent trends and progress, Immunol. Today 11 (1990) 427-429.

8. G. Gregoriadis, B. McCormack, M. Obrenovic, R. Saffie, B. Zadi and Y. Perrie, Vaccine entrapment in liposomes, Methods 19 (1999) 156-162; DOI: 10.1006/meth.1999.0841.

9. Y. Fujii, Y. Aramaki, T. Hara, K. Yachi, H. Kikuchi and S. Tsuchiya, Enhancement of systemic and mucosal immune responses following oral administration of liposomes, Immunol. Lett. 36 (1993) 65-69; DOI: 10.1016/0165-2478(93)90070-I.

10. A. Fortin and H. M. Therien, Mechanism of liposome adjuvanticity: an in vivo approach, Immunobiology 188 (1993) 316-322.

11. F. C. Szoka and D. Papahadjopoulas, Procedure for the preparation of liposomes with large aqueous space and high captures by reverse phase evaporation method, Proc. Natl. Acad. Sci. USA 75 (1978) 4194-4198.

12. D. W. Fry, J. C. White and I. D. Goldman, Rapid separation of low molecular weight solute from liposomes without dilution, Anal. Biochem. 90 (1978) 809-815; DOI: 10.1016/0003-2697(78)90172-0.

13. C. M. Stoscheck, Quantitation of protein, Methods Enzymol. 182 (1990) 50-68; DOI: 10.1016/0076-6879(90)82008-P.

14. P. N. Gupta, V. Mishra, A. Rawat, P. Dubey, S. Mahor, S. Jain, D. P. Chatterji and S. P. Vyas, Non-invasive vaccine delivery in transferosomes, niosomes and liposomes: a comparative study, Int. J. Pharm. 293 (2005) 83-91; DOI: 10.1016/j.ijpharm.2004.12.022. 
J. Madan et al.: Effect of ampicillin and chloroquine on humoral immune response elicited by bovine albumin encapsulated in liposomes, Acta Pharm. 58 (2008) 479-487.

15. J. M. Brewer and J. Alexander, The adjuvant activity of non-ionic surfactant vesicles (niosomes) on the BALB/c humoral response to bovine serum albumin, Immunology 75 (1992) 570-575.

16. H. Takeuchi, H. Kojima, H. Yamamoto and Y. Kawashima, Evaluation of circulation profiles of lipsomes coated with hydrophilic polymers having different molecular weights in rats, J. Control. Rel. 75 (2001) 83-91; DOI: 10.1016/S0168-3659(01)00368-6.

17. N. V. Katre, J. Asherman, H. Schaefer and M. Hora, Multivesicular liposomes (Depofoam) technology for the sustained delivery of insulin-like growth factor-1 (IGF-1), J. Pharm. Sci. 87 (1998) 1341-1346.

18. S. Nutten, A. Schumann, D. Donnicola, A. Mercenier, S. Rami and C. L. Garcia-Rodenas, Antibiotic administration early in life impairs specific humoral responses to an oral antigen and increases intestinal mast cell numbers and mediator concentrations, Clin. Vaccine Immunol. 14 (2007) 190-197; DOI: 10.1128/CVI.00055-06.

19. B. VanVlem, R. Vanholder, P. De Paepe, D. Vogelaers and S. Ringoir, Immunomodulating effect of antibiotics: literature review, Infection 24 (1996) 275-291.

20. G. J. Silerman, Human antibody response to bacterial antigens: studies of a model conventional antigen and a proposed model B cell super antigen, Int. Rev. Immunol. 9 (1992) 57-78.

\section{$S A \check{Z} E T A K$}

\section{Učinak ampicilina i klorokina na humoralnu imunošku reakciju na goveđi albumin kapsuliran u liposome}

JITENDER MADAN, DINESH KAUSHIK, SATISH SARDANA, DINA NATH MISHRA, SHALINDER KUMAR SINGH i BINOD KUMAR SINGHSNET

Na eksperimentalnim životinjama koje su prvo tretirane ampicilinom i klorokinom a zatim imunizirane goveđim serumskim albuminom s liposomima praćena je supresija imunološkog sustava i potencijalna interakcija lijekova. Liposomi su pripravljeni metodom reverzno-fazne evaporacije, a određena im je veličina čestica, količina supstancije koju mogu inkorporirati i oslobađanje in vitro. Humoralna imunološka reakcija praćena je određivanjem titra IgG antitijela ELISA metodom. Rezultati rada pokazuju da liposomi s fosfatidilkolinom iz soje i kolesterolom u molnom omjeru 7:3 imaju prosječni promjer $235.4 \pm 10.3 \mathrm{~nm}$ i sposobnost inkorporacije $41.3 \pm 3.2 \%$. Ampicilin je značajno $(p<0.05)$ smanjio titar antitijela, a klorokin nije. Ovi će rezultati biti korisni u programiranju novog režima primjene lijekova i u praćenju interakcije između cjepiva i lijeka.

Ključne riječi: imunomodulacija, liposomi, goveđi albumin, ampicilin, klorokin

Department of Pharmaceutics, Hindu College of Pharmacy, Sonepat (Haryana), India

Department of Pharmaceutical Sciences, Guru Jambheshwar University of Science and Technology, Hisar (Haryana) India

Department of Pharmacy, Kumaon University, Nainital, India 